Dialectologia 18 (2017), 95-106.

ISSN: 2013-2247

Received 24 December 2014.

Accepted 16 March 2015.

\title{
THE PHONOLOGICAL BEHAVIOUR OF NASAL SEGMENT IN ENGLISH LOANWORDS IN KELANTAN DIALECT
}

\author{
Sharifah Raihan SYed JAAFAR \& Sakinah Nik MUHAMmAd NAZIMAN \\ National University of Malaysia* \\ sakinah.niknaziman@gmail.com / s_raihan@ukm.edu.my
}

\begin{abstract}
This paper discusses the phonological behaviour of nasal segments in English loanwords in the Kelantan dialect of Malay. It has largely been discussed in previous Malay studies that nasal segments in words are finally deleted, as in /ikan/ $\rightarrow$ [ike] 'fish' and /jalan/ $\rightarrow$ [dzale] 'road'. The claims made by previous studies however cannot entirely hold for English words borrowed by the dialect. Based on previous data from Shapri (1980), this paper will show that some of the loanwords obey the grammar in that some nasal segments in word-final position are deleted and some are not. The obedience to grammar can be seen in words like 'attendant' [itand $\varepsilon$ ] and 'go astern' [gost $\varepsilon$ ]. Meanwhile, violation of the grammar can be seen in English words like 'canteen', 'agreement', 'accident' and 'cufflink', which are

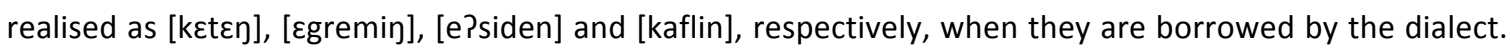
How obedience and violation occur with loanwords will be accounted for in this paper by adopting a constraint-based analysis, Optimality theory.
\end{abstract}

\section{Keywords}

Optimality theory, Kelantan dialect of Malay, nasal segment, English loanwords

\section{EL COMPORTAMIENTO FONOLÓGICO DEL SEGMENTO NASAL EN EL DIALECTO KELANTAN}

\section{Resumen}

Este artículo discute el comportamiento fonológico de los segmentos nasales en los préstamos ingleses en el dialecto kelantan de Malasia. En estudios malayos anteriores se ha discutido en gran

\footnotetext{
* School of Language Studies and Linguistics. Faculty of Social Sciences and Humanities. National University of Malaysia. 43600 Bangi, Malaysia.
} 
medida que los segmentos nasales en palabras se eliminan finalmente, como en /ikan/ $\rightarrow$ [ike] 'pez' y /jalan/ $\rightarrow$ [dzal $\varepsilon]$ 'carretera'. Sin embargo, las afirmaciones de estudios previos no se pueden mantener por completo para las palabras inglesas prestadas al dialecto. Basándose en los datos anteriores de Shapri (1980), este artículo mostrará que algunas de los préstamos obedecen a la gramática en que algunos segmentos nasales en posición final de palabra se eliminan y otros no. La obediencia a la gramática puede

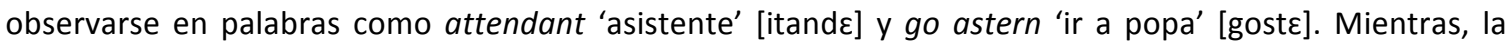
violación de la gramática puede observarse en palabras inglesas como canteen 'cantina', agreement 'acuerdo', accident 'accidente' y cufflink 'mancuernas', que se realizan respectivamente como [keten], [عgremin], [e?siden] y [kaflin], cuando son tomadas por el dialecto. En este artículo se dará cuenta de cómo se produce la obediencia y la violación en los préstamos se contabilizará mediante un análisis basado en restricciones, la teoría de la optimidad.

\section{Palabras clave}

teoría de la optimidad, dialecto Kelantan de Malasia, segmento nasal, préstamo del inglés

\section{Introduction}

Borrowing words from other languages is a common phenomenon in all natural languages. It has been broadly discussed by linguists who have studied loanwords in various subfields of linguistics, such as sociolinguistics, dialectology, phonology and morphology. In the world of phonology, with the rise of constraint-based analysis like Optimality theory, loanwords have received much formal attention from phonologists focusing more on the theoretical aspect of loanwords. There are some substantial works, such as Silverman (1992), Kenstowicz (2001; 2005), Broselow (2003), Yip (2002; 2006), Hwei-lin (2009), Mahmood et al. (2011).

In Malay, loanwords have also received much attention from linguists, e.g. Nik Safiah (1985), Ajid (1994), Hashim (1974), Farid (1980) and many others. It should be highlighted here that those previous works only discussed loanwords in a very descriptive way. No theoretical explanation is given in those analyses. Among the works mentioned above, none of them discusses the phonological aspect of the loanwords they examine. Thus this paper intends to offer a theoretical analysis to account for English loanwords in one of the Malay dialects i.e. the Kelantan dialect. By adopting constraint-based analysis called Optimality theory (henceforth, OT), this paper will 
discuss the phonological aspect of the dialect by focusing on nasal segments in wordfinal position in English loanwords.

It has long been claimed in previous studies that nasal deletion is always applied in the dialect when there is a final nasal segment in the word (e.g. Farid 1980, Ajid 1994 and others). In this analysis of English loanwords in the Kelantan dialect, this phonological requirement will be examined to see whether it also applies to loanwords. Besides this, other phonological aspects related to the aforementioned issue will also be discussed in this paper, e.g. vowel nasalisation.

In what follows, we discuss what has been done in previous Malay studies. This is then followed by a description of the theoretical framework used in the analysis and of OT analysis. A final section concludes the paper.

\section{Previous analyses on nasal segments in Kelantan dialect}

There are a number of previous Malay studies of the Kelantan dialect of Malay. Some substantial works are Nik Safiah (1985), Ajid (1994), Hashim (1974) and Farid (1980). The works mentioned above paid attention to the phonological system of the dialect which relates to the study i.e. nasal segments occupying the coda position of a syllable. It should however be mentioned that these studies do not offer any theoretical discussion in their analyses. The discussion of nasal segments is thus purely descriptive.

Nik Safiah (1985) claimed in her study that the dialect does not allow all consonants to surface in word-final position. She claims further that only hard palate and velar nasals, $/ \mathrm{h} /$ and $/ \mathrm{h} /$ respectively, as well as glottal stop $/ \mathrm{R} /$, are allowed to emerge at word-final position in the dialect. Farid (1980: 73) also discussed the occurrence of nasal segments at word-final position in Kelantan dialect. He claims that the Kelantan dialect deletes nasal segments in word-final position. In the dialect therefore we can see that words like dzulin 'cross-eye', ikan 'fish' and katam 'crab' are

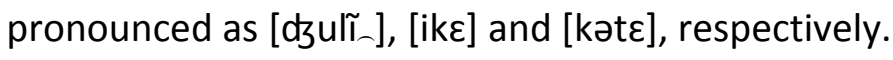

Similar to Farid (1980), Ajid (1994) also claims that the nasal segment at this morphological domain is deleted, while the vowel preceding the nasal segment gets a 
nasal feature which then becomes a nasalised vowel. The process of vowel nasalisation can clearly be seen in the following examples:

\begin{tabular}{|c|c|c|c|}
\hline Input & /malam/ & /dzalan/ & /udan/ \\
\hline Ascent of vocal & malem & dzalen & uden \\
\hline Nasalized vowel & malem & dzalen & uden \\
\hline Deletion of final nasal & male & dzale & ud $\tilde{\varepsilon}$ \\
\hline Output & [male] & [dzale] & [ude] \\
\hline
\end{tabular}

Table 1. Nasal Word-Final Position (from Ajid 1994)

In the analysis, Ajid (1994) also highlights that the vowel which precedes a nasal segment is somehow not nasalised. The following examples given by Ajid (1994) show that the vowel $[\varepsilon]$ in words $[i k \varepsilon],[s i \varepsilon]$ and $[s i \varepsilon]$ are not nasalised. Why they are not nasalised has however been left unexplained.

\begin{tabular}{|c|c|c|c|}
\hline Input & /ikan/ & /sian/ & /siam/ \\
\hline Ascent of Vocal & iken & sien & sicm \\
\hline Nasalized vowel & - & - & - \\
\hline Deletion of Final Nasal & $i k \varepsilon$ & sic & siદ \\
\hline Output & [ike] & [sic] & [sic] \\
\hline
\end{tabular}

Table 2. Nasal Word-Final Position (from Ajid 1994)

The studies discussed above, i.e. Ajid (1994) and Farid (1980), confirm that the phonological system of the Kelantan dialect does not prefer a nasal segment to emerge at word-final position. The segment thus undergoes deletion. In Nik Safiah's analysis on the other hand, it is claimed that only two types of nasal segments, i.e. $/ \mathrm{n} /$ and $/ \mathrm{h} /$, are allowed to be in this morphological domain.

Thus, in this study, we intend to examine this phonological restriction on English loanwords in Kelantan dialect. There are two questions that this paper seeks to answer. First, are English loanwords ending with nasal segments subject to the same phonological restriction as that imposed on native words, whereby the nasal segment at 
the end of a word is deleted? Second, is there any type of nasal segment that emerges in word-final position in the dialect as well as the two i.e. $/ \mathrm{n} /$ and $/ \mathrm{h} /$ claimed by Nik Safiah (1985)? In order to analyse how nasal segments in word-final position behave when English words are borrowed by the Kelantan dialect, data from a previous study by Shapri (1980) are used.

\section{Theoretical framework: Optimality theory}

In order to analyse the issue described above, a phonological theory, i.e. Optimality theory (henceforth, OT) which was proposed by Prince \& Smolensky (1993, 2004), is adopted in this study. The central idea of OT is that a grammar is a hierarchical ranking of well-formedness constraints which are specified in the Universal Grammar (UG). Individual grammars are constructed by imposing a language-particular ranking on those well-formedness constraints.

There are five basic tenets highlighted in OT which are summarized below (from McCarthy \& Prince 1994: 335):

\begin{tabular}{|c|c|}
\hline Universality & $\begin{array}{l}\text { UG provides a set of constraints that are universal. The constraints are } \\
\text { universally present in all grammars. }\end{array}$ \\
\hline Violability & Constraints are violable, but the violation must be minimal. \\
\hline Ranking & $\begin{array}{l}\text { The constraints of Con are ranked on a language-particular basis. The } \\
\text { minimal violation is defined in terms of this ranking. }\end{array}$ \\
\hline Inclusiveness & $\begin{array}{l}\text { The constraints hierarchy evaluates a set of candidates that are admitted by } \\
\text { very general considerations of structural well-formedness. }\end{array}$ \\
\hline Parallelism & $\begin{array}{l}\text { The best satisfaction of the constraints hierarchy is evaluated over the } \\
\text { whole hierarchy and the whole candidate set. There is no serial } \\
\text { derivation. }\end{array}$ \\
\hline
\end{tabular}

Table 3. Five basic tenets of OT 
In OT, the actual output of the underlying form is selected from a large set of potential surface forms called candidates. The selection of candidates is based on wellformedness constraint-system evaluation. The representational structure of a grammar in OT can be summarised as follows (McCarthy \& Prince 1993, 1994):

GEN $($ in $)=\{$ cand 1, cand $2, \ldots$.

EVAL (\{cand 1 , cand $2, \ldots\}$.

The function of GEN (short for generator) will generate a large set of possible candidates (surface representation) from each input (underlying representation). The function of EVAL (short for evaluator) will evaluate the well-formedness of the possible candidates generated by GEN. The candidate which best satisfies, or minimally violates the constraints in a hierarchy is termed as the optimal or most harmonic output, and constitutes the actual surface form in the language. The best output is evaluated by a set of constraints which is ranked hierarchically in a grammar. This set of constraints ranking is represented in a constraint tableau, as illustrated below. There are some useful conventions to be found in the constraint tableau. Constraints in OT are represented from left to right, where the leftmost side is the highest-ranking constraint, which should be highly obeyed. Potential candidates are listed in vertical order. Violation of a constraint is marked by '*', while constraint satisfaction is unmarked. The violation of a constraint which is accompanied by an exclamation mark, '!', indicates a fatal violation. The optimal output is shown by a pointing finger ' $F$ '.

$$
\text { /Input/ } \rightarrow \text { [cand1], A >> B }
$$

\begin{tabular}{|l||l|l|}
\hline /Input/ & \multicolumn{1}{|c|}{ A } & \multicolumn{1}{c|}{ B } \\
\hline \hline a.F[candidate] & & $*$ \\
\hline b. $[$ candidate] & $* !$ & \\
\hline
\end{tabular}

In the above tableau, the suboptimal candidate (b) is ruled out as it fatally violates constraint A. Candidate (a), which violates the lower-ranking constraint $B$, is the optimal output. The violation of constraint $B$, however, is not significant anymore since the 
winner has already been determined. In OT, the remaining lower-ranking constraint becomes irrelevant once a winner emerges. The violation of constraints after that does not affect its grammaticality.

\section{OT Analysis}

In this section, we are going to discuss how a nasal segment occupying the coda position of a syllable is actually treated when English words are borrowed by the Kelantan dialect. As was discussed above, previous studies merely focused on Malay words. None of them has discussed English loanwords or any other languages in the Kelantan dialect of Malay. The studies therefore lack some important findings that should also be discussed when examining the phonological system of the dialect. It ought to be mentioned when considering English loanwords that nasal segments in word-final position in Kelantan dialect exhibit two different phonological behaviours, i.e.: (1) the segment undergoes deletion; (2) the segment does not undergo deletion, whereby another type of nasal segment emerges in word-final position.

We now discuss the first phonological behaviour found from the data, i.e. a nasal segment undergoes deletion. Deletion of the nasal causes the vowel preceding the nasal to be nasalised. This supports what Farid (1980) and Ajid (1994) claimed regarding nasal deletion in word-final position in the dialect, as discussed above. We exemplify the following relevant examples from Shapri (1980):

\section{English loanwords}

Attendant

Go astern
In Kelantan dialect

itand $\varepsilon$

gost $\varepsilon$

Table 4. Nasal deletion and nasalisation vowel in word-final position

The relevant constraint for English loanwords in Kelantan dialect:

DEP-IO: Output segments must have input correspondents (no epenthesis) (Kager 1999). 
CODA COND: A coda can contain place features only when these are simultaneously associated with a syllable position outside the coda. (Itô \& Mester 1994)

MAX-IO: Input segments must have output correspondents (no deletion) (Kager 1999).

Non-high : Non-high vowels are dispreferred everywhere (Crosswhite 2000: 10).

* $\mathrm{V}_{\text {nas }}$ : Assign one violation mark for every nasalized vowel (McCarthy 2008)

In what follows, we establish an OT tableau to account for the word [dzalc].

\begin{tabular}{|l|c|c|c|c|c|}
\hline /dzalan/ & DEP-IO & $\begin{array}{c}\text { CODA } \\
\text { COND }\end{array}$ & Non-high & MAX-IO & $* V_{\text {nas }}$ \\
\hline a. dzalan & & $* !$ & $* *$ & & \\
\hline b. dzala & & & $* * !$ & $*$ & \\
\hline c. dzalanə & $* !$ & & $* * *$ & & \\
\hline d. dzal & & & $*$ & $* !$ & $*$ \\
\hline
\end{tabular}

It is clear from the above tableau that the nasal-final consonant in /dzalan/ is deleted. The markedness constraint in the ranking, i.e. CODA COND, penalises a place nasal segment which occupies the coda position in the syllable. This constraint rules out candidate (a) with a nasal segment in the coda position of the second syllable. Candidate (c) is ruled out by the faithfulness constraint DEP-IO since the epenthesis vowel is one of the strategies to prevent the nasal segment from occupying the coda syllable. Candidate (b), which violates the non-high constraint twice as the vowel [a], emerges twice in the word. Therefore this candidate is ruled out. Candidate (d), which violates the lowranked constraint i.e. MAX-IO, thus emerges as the winner.

We have seen the first phonological behaviour of the nasal segment in word-final position in the dialect, i.e. the nasal segment undergoes deletion while the vowel before the nasal is nasalised. Now, we come to examine the phonological behaviour of the nasal segment in the Kelantan dialect, i.e. from the English loanwords data. The nasal segment in this morphological domain, i.e. the final nasal, does not undergo deletion, thus another type of nasal segment emerges. Before we offer an OT account for this, let us look at some relevant examples from Shapri (1980): 


$\begin{array}{ll}\text { English loanwords } & \text { In Kelantan dialect } \\ \text { accident } & \text { e?siden } \\ \text { ball pen } & \text { bolpe:n } \\ \text { ceiling } & \text { selen } \\ \text { company } & \text { kJpenin } \\ \text { cufflink } & \text { kaflein } \\ \text { guardroom } & \text { ga?ro:n } \\ \text { machine gun } & \text { mesein gen } \\ \text { peon } & \text { piju:n } \\ \text { second-hand } & \text { sekenhen } \\ \text { statement } & \text { ste?min }\end{array}$

Table 5. Nasal segment in word-final position

The English loanwords data presented above clearly show that nasal segments in word final position are retained in Kelantan dialect. In OT, the markedness and faithfulness constraints are ranked in a particular manner. In loanwords phonology, the ranking for loans can differ from the native words in terms of the ranking of faithfulness constraints. This is called loan-sensitive faithfulness constraints output-output (O-O) constraints. To deal with the undeleted nasal segment in word-final position in English loanwords in the Kelantan dialect, an O-O faithfulness constraint needs to be considered in the constraint ranking, as the output of the English words is the input for the native words. Below, I briefly illustrate a model for loanwords adaptations in the dialect:

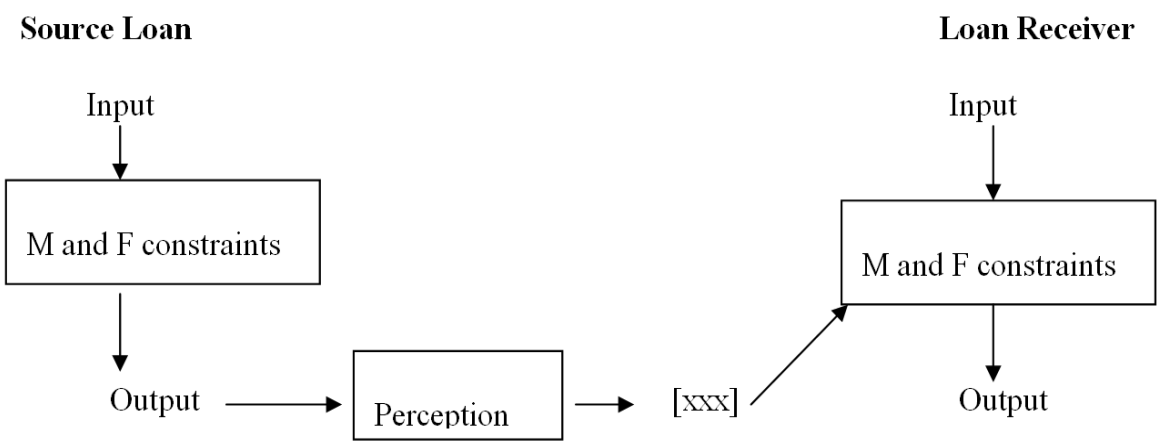

Graphic 1. Model of English Loanwords Adaptation in the Kelantan dialect 
There are three different ways that can be identified that correspond to loanword adaptation (see Kenstowicz 2005). One which is relevant to the issue under discussion is by ranking a relevant $\mathrm{O}-\mathrm{O}-\mathrm{faithfulness}$ constraint above the markedness constraint(s) in the constraint ranking that enforces the phonotactic (ibid.) of the Kelantan dialect: OOIDENT[F] >> M > IO-IDENT[F]. In this analysis, the relevant OO-Faithfulness that should be considered in the ranking is MAX-OO. Below, we establish the tableau for the English loanwords /kanti:n/.

\begin{tabular}{|l|c|c|c|c|c|c|}
\hline /kanti:n/ & $\begin{array}{c}\text { MAX- } \\
\text { OO }\end{array}$ & $\begin{array}{c}\text { DEP- } \\
\text { IO }\end{array}$ & $\begin{array}{c}\text { CODA } \\
\text { COND }\end{array}$ & $\begin{array}{c}\text { Non- } \\
\text { high }\end{array}$ & MAX-IO & ${ }^{*} V_{\text {nas }}$ \\
\hline a. ${ }^{*}$ kanti:n & & & $* !$ & $*$ & & \\
\hline b. kanti & $* !$ & & & $*$ & & \\
\hline c. kant $\tilde{\varepsilon}$ & $* !$ & & & $*$ & & $*$ \\
\hline d. kantinə & & $* !$ & & $* *$ & & \\
\hline
\end{tabular}

\section{Conclusion}

The discussion above shows that by considering English loanwords in the Kelantan dialect of Malay, the phonological requirement imposed on native words is not fully obeyed. It is observed that the native phonological requirement that is nasal segment which is always deleted in word-final position in the dialect could not be satisfied in English loanwords. The data reveal that an alveolar nasal emerges on the surface, whereas the dialect disfavours the occurrence of it at word-final position.

\section{References}

AJID, Che Kob (1994) "Nasal di Akhir Kata Dalam Dialek Melayu”, Zaharani Ahmad (ed.), Linguistik Melayu: Festchrift Tinta Kenangan Sempena Persaraan Azhar M. Simin \& Farid M. Onn, Bangi: Jabatan Linguistik, Universiti Kebangsaan Malaysia, 147-158. 
BroseloW, Ellen (2003) "Language contact phonology: richness of the stimulus, poverty of the base", in Keir Moulton \& Matthew Wolf (eds.), Proceedings of the North-Eastern Linguistic Society, 34, Amherst, Massachusetts: Graduate Linguistic Student Association, 1-22.

CROSSWHITE, Katherine (2000) "The Analysis of Extreme Vowel Reduction", in Adam Albright \& Taehong Cho (eds.), UCLA Working Papers in Linguistics, 4, Papers in Phonology, 4, 1-12.

FARID, M. Onn (1980) Aspects of Malay Phonology and Morphology: A Generative Approach, Bangi: Universiti Kebangsaan Malaysia.

HASHIM, Musa (1974) Morfemik Dialek Melayu Kelantan, Tesis M.A., Kuala Lumpur: Universiti Malaya.

HWEI-LIN, Yen (2009) "Loanword Adaptation and Phonological Theory", in Yun Xiao (ed.), Proceedings of the 21st North American Conference on Chinese Linguistics (NACCL-21), Volume 1, Smithfield, Rhode Island: Bryant University, 1-12.

ITÔ, Junko \& Armin MeSTER (1994) "Realignment", in Rene Kager, Harry van der Hulst \& Wim Zonneveld (eds.), The Prosody Morphology Interface, Cambridge: Cambridge University Press, 188-217.

KAGER, Rene (1999) Optimality theory, Cambridge: Cambridge University Press.

Kenstowicz, Michael (2001) "The Role of Perception in Loanword Phonology", Linguistique Africaine, 20, 95-112.

KenstowiCZ, Michael (2005) "The Phonetics and Phonology of Korean Loanword Adaptation”, in Sang-Jik Rhee (ed.), Proceedings of the first European conference on Korean linguistics, Seoul: Hankook Publishing Co., 17-32.

MCCARTHY, John (2008) Doing Optimality Theory: applying theory to data, Oxford: Blackwell Publishing.

MCCARTHY, John J. \& Alan S. PRINCE (1993) Prosodic morphology: constraint interaction and satisfaction, Amherst, University of Massachusetts.

McCARThY, John J. \& Alan S. PRINCE (1994) "The emergence of the unmarked: Optimality in prosodic morphology", in M. González (ed.), Proceedings of the North East Linguistic Society, 24, Amherst, Massachusetts: Graduate Linguistic Student Association, 333-379.

NIK SAFIAH, Karim (1985) "Dialek Kelantan - Satu Lambang Sosio-Budaya Wilayahnya", in Nik Safiah Karim \& Wan Abdul Kadir Yusoff (ed.), Kelantan dalam Perspektif Sosio-Budaya: Satu Kumpulan Esei, Kuala Lumpur: Universiti Malaya, 121-149. 
PRINCE, Alan \& Paul SMOLENSKY (1993) Optimality theory: constraint interaction in generative grammar, Rutgers University Center for Cognitive Science Technical Report <Available on Rutgers Optimality Archive, ROA-537>.

PrINCE, Alan \& Paul SMOLENSKY (2004) Optimality theory: constraint interaction in generative grammar, Malden, Mass: Blackwell.

MAHMOOD, Rashid, Qandeel HUSSAIN \& Asim MAHMOOD (2011) "Phonological adaptations of English words borrowed into Punjabi", European Journal of Social Sciences, 22(2), 234245.

SHAPRI, Ab. Llah. (1980) "Perkataan-Perkataan Inggeris di dalam Pertuturan Bahasa Melayu Dialek Kelantan: Suatu Tinjauan yang Menyeluruh, Latihan IImiah Ijazah Sarjanamuda Sains Sosial dan Kemanusiaan, Bangi: Universiti Kebangsaan Malaysia.

SILVERMAN, Dan (1992) "Multiple Scansions in Loanword Phonology: Evidence from Cantonese", Phonology, 9, 289-328. 